Em 13 de março de 2010 faleceu na cidade de Campinas, São Paulo, a Dra. Ellen Hardy (1939-2010), pesquisadora na área de Sociologia abordando temas em saúde e ditreitos da mulher e bioética. A Revista Brasileira de Saúde Materno Infantil reconhecendo a importância da Dra. Ellen neste cenário, solidariza-se com os seus familiares e publica aqui o seu obtuário.

\title{
Ellen Hardy (1939-2010)
}

Ellen Hardy foi socióloga, doutora em saúde pública, nascida na Argentina, naturalizada chilena e que viveu no Brasil por quase 34 anos. Era pesquisadora... mas não apenas isso... principalmente, foi bem mais que isso. Em seu memorial, apresentado ao Departamento de Tocoginecologia da Faculdade de Ciências Médicas da Universidade de Campinas (UNICAMP), no ano 2000, ela reconhecia que tinha tido "uma vida de cigana, tendo morado em sete países, nove cidades e inúmeras casas". Ela dizia que profissionalmente nasceu no Chile, cresceu na República Dominicana e amadureceu no Brasil. Esse percurso geográfico evoca a trajetória de vida de uma pessoa que percorreu caminhos e ocupou espaços diversos ao longo de sua vida: inseriu-se na vida social como a grande maioria de suas contemporâneas, dedicando-se exclusivamente ao marido, aos filhos e à casa; despertou para suas outras potencialidades e vislumbrou a possibilidade de ser também uma profissional, quando precisou lutar muito para conciliar essas distintas facetas do que significa ser mulher.

A luta pela equidade de gênero sempre permeou a trajetória de Ellen, levando-a, sempre a preocupar-se com situação das mulheres nos diferentes contextos, e fazendo com que procurasse usar seus conhecimentos e posições alcançadas para promover melhores condições de vida e desenvolvimento para as mulheres. Uma ação marcante em sua carreira foi a idealização e a implementação do Centro de Convivência Infantil (CECI)da Universidade de Campinas (UNICAMP), entre 1982 e 1983, visando a garantir na universidade o direito das mulheres trabalhadoras poderem deixar seus filhos pequenos em segurança e amamentá-los durante a jornada de trabalho. Essa instituição, desde então, abriga os filhos de funcionárias, docentes e alunas da universidade.

$\mathrm{Na}$ defesa da equidade de gênero, Ellen também rompeu barreiras ao ocupar cargos e postos antes tidos como atribuíveis apenas a homens, bem como sempre foi questionadora dos estereótipos de gênero em nossa sociedade e defensora da abertura de novos espaços legítimos para participação das mulheres. A essa postura constante de defesa dos direitos das mulheres, somou o trabalho incansável de integrar ciências sociais e biomédicas em seu ofício de pesquisadora e professora. Foi a primeira mulher e cientista social a ocupar a presidência (1997-2001) da Asociación Latinoamericana de Investigadores em Reproducción Humana (ALIRH). Antes disso, também foi pioneira em defender a inclusão de cientistas sociais no rol de membros da ALIRH e conseguir recursos para que esses profissionais pudessem estar presentes às reuniões bienais, em diversos países da América Latina.

Esforço e persistência também foram marcantes em sua luta por construir e consolidar seu espaço como pesquisadora e professora, desenvolvendo estudos na interface das pesquisas sociais com as biomédicas, ensinando a jovens aprendizes e pesquisadores o ofício e a aventura de fazer pesquisa em países periféricos, com poucos recursos, mas com muito rigor e disposição. Com essa perspectiva, a Dra. Ellen Hardy marcou a formação de muitos pesquisadores, especialmente no Centro de Pesquisas em Saúde Reprodutiva de Campinas (Cemicamp) e no Departamento de Tocoginecologia da Faculdade de Ciências Médicas da UNICAMP. Foi a primeira presidente (1988-1995) da Comissão de Pesquisa desse Departamento, que voltou ainda a presidir em um segundo momento (2006-2008); foi responsável pela disciplina de Metodologia da Pesquisa em Reprodução Humana I por muitos anos (1991-2008), tendo, inclusive, publicado um livro ${ }^{1}$ que continua a ser referência para os alunos de pós-graduação não apenas nesse Departamento. Nos últimos anos, apaixonou-se pela bioética e dedicou boa parte de seu tempo a estudar, pesquisar e ensinar sobre esse tema, além de participar do Comitê de Ética em Pesquisa da Faculdade de Ciências Médicas da UNICAMP (1997-2001). Coordenou a primeira avaliação do Sistema CEP/CONEP no Brasil, em um projeto de pesquisa apoiado pelo CNPq/Departamento de Ciência e Tecnologia do Ministério da Saúde. 
Ellen alcançou os foros acadêmicos e de pesquisa no cenário internacional mas, como ela mesma dizia, sempre sentiu-se latino-americana e tentou utilizar seus conhecimentos e capacidades na região. O legado que ela nos deixa compreende não apenas suas tantas publicações (119 artigos completos em periódicos, seis livros e 23 capítulos de livros), somadas ao seu empenho, competência e dedicação no exercício da docência e da pesquisa. Esse legado inclui, sem dúvida, também seu exemplo de pessoa que precisou enfrentar e superar muitos obstáculos, conviver com certezas e dúvidas, afirmações e contradições, para obter suas conquistas. É o legado de um ser humano. Nada melhor do que dar-lhe a palavra para uma auto-reflexão, também expressa no memorial do ano 2000:

"Nesta altura da vida decidi falar em primeira pessoa. Creio que é um privilégio permitido pela idade e pelas conquistas ao longo de minha vida... Este é um período de reflexão sobre o passado e o que resta do futuro. Tive uma vida com experiências muito negativas e tristes e também rica em experiências positivas. Entre as primeiras, sobressai o êxodo forçado do Chile. De positivo, a longa convivência com meu marido com cujo apoio tenho contado sempre... Sou muito grata a ele. Além disso, meus filhos, que têm me dado muitas satisfações e motivos de orgulho, tanto do ponto de vista afetivo quanto pelas conquistas em suas vidas. Por último, quero ressaltar a felicidade que a simples existência de meus netos tem significado para mim. Não tenho palavras para expressar o quanto eles, os quais eu não esperava, tão ocupada estava com minhas coisas, têm enriquecido meu viver.”

Dra. Maria José Osis, Cemicamp

Coordenadora do Departamento de Pesquisas Sociais do Cemicamp.

\section{Bibliografia}

${ }^{1}$ Hardy E. Instruções para escrever um projeto de pesquisa. Campinas: Cemicamp; 2002. 